\title{
Transtornos afetivos: pesquisa e perspectivas para o futuro
}

\begin{abstract}
Resumo
Neste breve comentário, áreas particularmente promissoras de pesquisa básica e clínica que visam elucidar a etiologia e fisiopatologia dos transtornos afetivos são sumarizadas. Perspectivas para pesquisa e desenvolvimento futuro são brevemente discutidas, com ênfase particular em possibilidades para o desenvolvimento de novas intervenções terapêuticas para esses transtornos.
\end{abstract}

\section{Descritores}

Transtornos afetivos; depressão; etiologia; fisiopatologia; tratamento

\begin{abstract}
Important new areas of basic and clinical research that attempt to elucidate the etiology and pathophysiology of mood disorders are briefly summarized. Particular emphasis is given to research that may contribute to the development of new therapeutic interventions for these disorders. Perspectives for development in these areas are briefly discussed, and future directions are suggested.
\end{abstract}

\section{Keywords}

Mood disorders; depression; etiology; pathophysiology; treatment

\section{Introdução}

Transtornos afetivos, unipolares e bipolares, são muito prevalentes na comunidade geral e na prática clínica, e causam sofrimento humano importante, assim como perda econômica substancial para a sociedade. ${ }^{1-4}$ Apesar de numerosas investigações ao longo das últimas décadas, a etiologia e fisiopatologia desses distúrbios ainda são, em sua maior parte, desconhecidas. Recentemente, atrelados a avanços consideráveis nas neurociências, um número cada vez maior de estudos básicos e clínicos tem se dedicado a tentar esclarecer a fisiopatologia desses distúrbios. Neste breve comentário, áreas de pesquisa particularmente promissoras em relação aos transtornos afetivos serão discutidas.

\section{Perspectivas para esclarecimento da fisiopatologia}

Relatos recentes sugerem alterações anatômicas discretas, assim como alterações funcionais e neuroquímicas no cérebro de pacientes com transtornos afetivos. ${ }^{5-11}$ Desenvolvimentos apreciáveis nas metodologias de tomografia computadorizada por emissão de fóton único (Spect), tomografia por emissão de pósitron (PET), e ressonância nuclear magnética (MRI), tanto funcional (fMRI), quanto por espectroscopia (MRS), tem ocorrido nos últimos anos. Já a anatomia, assim como processos fisiológicos e neuroquímicos do cérebro de pacientes vivos começam a ficar acessíveis ao estudo direto. ${ }^{12-14}$ Entre as alterações anatômicas identificadas, há relatos de anomalias em córtex préfrontal, gânglios da base, cerebelo, e estruturas mediais do lobo temporal. ${ }^{5,9, *}$ Alterações funcionais, refletidas em alterações de fluxo sangüíneo e metabolismo de glicose cerebrais, têm também sido encontradas em várias dessas mesmas regiões cerebrais. ${ }^{6,715}$ Estudos preliminares in vivo de receptores cerebrais sugerem alterações nos sistemas serotonérgico e dopaminérgico. ${ }^{11,166^{* *}}$ Investigações com 31P e 1 H MRS sugerem alterações em processos de membrana e metabolismo neuronais. ${ }^{17,18}$ Em conclusão, essas novas áreas de pesquisa têm um potencial enorme para resultar na elucidação dos mecanismos cerebrais envolvidos nesses distúrbios. Tais mecanismos, se identificados, podem propiciar alvos específicos para o desenvolvimento farmacoterapêutico futuro.

Outra área recente de pesquisa é a investigação de processos intracelulares pós-receptor, ou marcadores intracelulares de transdução de sinais. Em vários estudos, tem-se tentado caracte-

\footnotetext{
* Soares J, Innis R. Brain imaging findings in bipolar disorder. In: Soares J, Gershon J, editors. Basic mechanisms and therapeutic implications of bipolar disorder. New York (NY): Marcel Dekker; 1999: in press.
}

1. Neurochemical Brain Imaging Laboratory. Departamento de Psiquiatria, Western Psychiatric Institute and Clinic, Universidade de Pittsburgh, Pensilvânia (EUA). 
rizar disfunções em processos intracelulares pós-receptor em pacientes bipolares e unipolares. ${ }^{19-24,{ }^{*}}$ Há dados preliminares que sugerem que disfunções nesses mecanismos possam estar envolvidas na fisiopatologia desses transtornos, e que essas possam ser importantes para o mecanismo de ação de medicações efetivas para esses distúrbios. Tentativas inovadoras de estudar esses processos diretamente no cérebro de pacientes vivos com métodos de neuroimagem estão em andamento, ${ }^{25-27}$ e avanços nessas áreas, quando disponíveis, serão de suma importância.

Novos estudos têm focalizado em tentativas de elucidação dos mecanismos de vulnerabilidade genética nos transtornos afetivos. Juntamente com fatores ambientais, certos genes, ou combinações de genes, podem eventualmente conferir uma suscetibilidade aumentada para o desenvolvimento desses distúrbios. Essas investigações têm sido dificultadas pelo fato de esses transtornos provavelmente terem herança multigênica. Entre as investigações conduzidas, há achados positivos interessantes, ${ }^{28-32}$ mas até o momento, os resultados desses estudos têm sido predominantemente negativos. ${ }^{33-38} \mathrm{~A}$ elucidação desses mecanismos poderá oferecer no futuro oportunidades para predizer o risco individual de se desenvolver esses transtornos, ou para se predizer a probabilidade de resposta terapêutica a tipos particulares de tratamentos. Desenvolvimentos nesta área podem também resultar em possibilidades futuras de intervenções terapêuticas inovadoras como terapia genética. Com o progresso do projeto do genoma humano, e desenvolvimento de novas metodologias para pesquisas genéticas, esta é uma área de investigação que deverá ser muito beneficiada.

Outra área embrionária de muita importância tem sido o estudo do desenvolvimento cerebral, em relação à vulnerabilidade futura para os transtornos afetivos. Algumas linhas de investigação sugerem que insultos cerebrais precoces (em período intra-útero ou neonatal), ou cedo na infância, possam resultar em mudanças cerebrais permanentes, que eventualmente causariam ou contribuiriam para uma predisposição ao desenvolvimento de transtornos afetivos futuros. Alguns autores têm sugerido que infecções virais, privações alimentícias, maus tratos e abuso na infância durante o desenvolvimento podem estar entre tais fatores. ${ }^{39-42}$ Adversidades ao longo da vida também são fatores de risco importantes. ${ }^{43,44}$ Estresse sabidamente interage com mecanismos neuro-hormonais, e pode afetar o desenvolvimento cerebral, e também alterar funções de áreas específicas no cérebro já desenvolvido, podendo eventualmente resultar em predisposição aumentada, ou início de um distúrbio afetivo. ${ }^{45,46}$ Esses mecanismos precisam ser investigados, e potencialmente elucidados em estudos futuros, de modo que esta é uma área em que avanços importantes poderão acontecer.

\section{Perspectivas para o tratamento}

A busca de medicações antidepressivas que possam ter início de ação mais rápido tem sido uma área importante em pesquisa clínica. ${ }^{47-49}$ Há estratégias que têm sido propostas, mas até o momento as alegações de que alguns tratamentos específicos têm início de ação mais rápido não tem sido, de maneira geral, comprovadas.

Em relação ao tratamento dos distúrbios bipolares, há uma percepção cada vez maior de que o curso desses distúrbios é mais gravedo que sugerido pelos estudos iniciais, ${ }^{3,50}$ e que $40 \%$ $50 \%$ dos pacientes não responderão satisfatoriamente ao lítio. Novas medicações que são benéficas para a fase aguda, e provavelmente também para a profilaxia desses distúrbios já estão disponíveis, como carbamazepina e valproato, e outras novas possibilidades começam a ser testadas, como lamotrigina, gabapentina, e topiramato, o que poderá propiciar novas alternativas para pacientes refratários, ou que são sensíveis aos efeitos colaterais do lítio. O desenvolvimento de um estabilizador do humor que não contribua para aumento de peso corpóreo, que é um efeito colateral problemático e muito comum entre esses pacientes, como se propõe ser o caso para o topiramato, será um desenvolvimento muito relevante. Estudos clínicos específicos devem investigar esta possibilidade.

Em relação aos transtornos depressivos recorrentes, com episódios múltiplos, outro desenvolvimento importante é a constatação de que tais casos geralmente necessitarão de tratamento medicamentoso por múltiplos anos, e que se beneficiam mais de tratamento a longo prazo com as mesmas doses de medicações antidepressivas que foram utilizadas para a fase aguda do tratamento. ${ }^{51}$

A depressão em pacientes bipolares tem sido reconhecida como um dilema terapêutico, sobre o qual há, comparativamente, pouca informação disponível. ${ }^{52}$ Há estudos sugerindo que tais casos sejam menos responsivos a tratamento medicamentoso do que inicialmente se supôs.${ }^{53}$ É comum que o tratamento antidepressivo desses pacientes resulte em ciclagem para a mania, ${ }^{54}$ e que talvez este possa contribuir para tornar esses pacientes cicladores rápidos, refratários ao tratamento ${ }^{55}$ Portanto, o desenvolvimento futuro de novas estratégias para este grupo particular de pacientes será muito relevante.

Comorbidades diagnósticas, como abuso de substância, ou transtornos de personalidade, tornam o tratamento destes transtornos particularmente difícil, com taxas de refratariedade substancialmente mais altas. ${ }^{56,57}$ Essas comorbidades tornam o tratamento mais complexo, multifacetado, e intervenções psicossociais, em conjunto com farmacológicas, assumem aqui importância fundamental.

Modelos psicoterápicos que possam ser empiricamente testados e validados têm sido desenvolvidos, e esta é outra área de pesquisa essencial que deve se desenvolver nos próximos anos. Alguns exemplos já existem de intervenções especificamente desenvolvidas para grupos específicos de pacientes, e que começam a ser empiricamente testadas e validadas..$^{58,59}$ É gratificante ver que este campo do conhecimento começa mais e mais a buscar métodos de intervenção que possam ser devidamente testados, de modo que os tratamentos oferecidos aos nossos pacientes consistam de intervenções cuja eficácia tenha sido devidamente examinada.

O suicídio é muito freqüente em pacientes com transtornos afetivos, e é causa importantíssima de perdas humanas. De

* Soares JC, Mallinger AG. Intracellular signal transduction dysfunction in bipolar disorder. In: Soares JC, Gershon S, editors. Basic Mechanisms and Therapeutic Implications of Bipolar Disorder. New York (NY): Marcel Dekker; 1999: in press. 
maneira geral, não há métodos satisfatórios para predizê-lo, ou preveni-lo. Talvez o desenvolvimento de marcadores biológicos sensíveis, capazes de identificar precocemente pacientes com alto risco para o suicídio, possa contribuir para avanços significativos neste campo. ${ }^{60}$

\section{Conclusão}

Vivemos numa época muito estimulante e encorajadora para a prática psiquiátrica clínica. Avanços claros e decisivos estão nos colocando cada vez mais próximos do esclarecimento da etiopatogenia dos vários distúrbios psiquiátricos, inclusive dos transtornos afetivos. Progressivamente, novas alternativas terapêuticas vão sendo identificadas e devidamente testadas. Isto nos dá a confiança de que no novo milênio teremos cada vez mais recursos efetivos para oferecer aos pacientes que sofrem desses onerosos transtornos.

\section{Agradecimentos}

Agradececimentos à Sra. Hiroko Soares por assistência técnica na preparação e revisão deste manuscrito.

\section{Referências bibliográficas}

1. Smith A, Weissman M. Epidemiology. In: Paykel E, editor. Handbook of affective disorders. New York (NY): The Guilford Press; 1992. p. 111-29.

2. Akiskal HS. The prevalent clinical spectrum of bipolar disorders - beyond DSM-IV. Journal of Clinical Psychopharmacology 1996;16(2 Suppl 1):4-14.

3. Gershon S, Soares JC. Commentary - Current therapeutic profile of lithium. Archives of General Psychiatry 1997;54:16-20.

4. Angst J. Comorbidity of mood disorders - a Longitudinal Prospective Study. British Journal of Psychiatry 1996;168(Suppl 30):31-7.

5. Soares JC, Mann JJ. The anatomy of mood disorders - Review of structural neuroimaging studies. Biological Psychiatry 1997;41:86-106.

6. Soares JC, Mann JJ. The functional neuroanatomy of mood disorders. Journal of Psychiatric Research 1997;31(4):393-432.

7. George MS, Ketter TA, Post RM. SPECT and PET imaging in mood disorders. Journal of Clinical Psychiatry 1993;54 Suppl:6-13.

8. Drevets WC. Functional neuroimaging studies of depression: the anatomy of melancholia. Annu Rev Med 1998;49:341-61.

9. Steffens DC, Krishnan KR. Structural neuroimaging and mood disorders: recent findings, implications for classification, and future directions. Biol Psychiatry 1998;43(10):705-12.

10. Soares JC, Krishnan KR, Keshavan MS. Nuclear magnetic resonance spectroscopy: new insights into the pathophysiology of mood disorders. Depression 1996;4(1):14-30.

11. Mann JJ. The role of in vivo neurotransmitter system imaging studies in understanding major depression. Biological Psychiatry 1998;44:1077-8.

12. Malison RT, Laruelle M, Innis RB. Positron and single photon emission tomography. In: Bloom FE, Kupfer DJ, editors. Psychopharmacology: The Fourth Generation of Progress. New York (NY): Raven Press; 1995. p. 865-79.

13. Keshavan MS, Kapur S, Pettegrew JW. Magnetic resonance spectroscopy in psychiatry: potential, pitfalls, and promise. American Journal of Psychiatry 1991;148(8):976-85.

14. Pettegrew JW. Nuclear magnetic resonance spectroscopy: principles and applications to neuroscience research. In: Boller F, Grafman J, editors. Handbook of Neuropsychology. vol. 5. Amsterdam, Netherlands: Elsevier Science Publishers; 1991. p. 39-56.

15. Mayberg HS. Limbic-cortical dysregulation: a proposed model of depression. The Journal of Neuropsychiatry and Clinical Neurosciences 1997;9:471-81.

16. Staley JK, Malison RT, Innis RB. Imaging of the serotonergic system: Interactions of neuroanatomical and functional abnormalities of depression. Biological Psychiatry 1998;44:534-49.

17. Soares JC, Krishnan KRR, Keshavan MS. Nuclear magnetic resonance spectroscopy - New insights into the pathophysiology of mood disorders. Depression 1996;4:14-30.

18. Kato T, Inubushi T, Kato N. Magnetic resonance spectroscopy in affective disorders. Journal of Neuropsychiatry and Clinical Neurosciences 1998;10:133-47.

19. Lenox RH, McNamara RK, Watterson JM, Watson DG. Myristoylated alanine-rich C kinase substrate (MARCKS): a molecular target for the therapeutic action of mood stabilizers in the brain? J Clin Psychiatry 1996;57 Suppl 13:23-33.

20. Manji HK, Chen G, Shimon H, Hsiao JK, Potter WZ, Belmaker RH.
Guanine nucleotide-binding proteins in bipolar affective disorder. Effects of long-term lithium treatment. Archives of General Psychiatry 1995;52(2):135-44.

21. Soares JS, Mallinger AG. Intracellular phosphatidylinositol pathway abnormalities in bipolar disorder patients. Psychopharmacology Bulletin 1997;33(4):685-91.

22. Dubovsky SL, Murphy J, Christiano J, Lee C. The calcium second messenger system in bipolar disorders: data supporting new research directions. J Neuropsychiatry Clin Neurosci 1992;4(1):3-14.

23. Manji HK, Bersudsky Y, Chen G, Belmaker RH, Potter WZ. Modulation of protein kinase $\mathrm{C}$ isozymes and substrates by lithium: the role of myoinositol. Neuropsychopharmacology 1996;15(4):370-81.

24. Lenox RH, McNamara RK, Papke RL, Manji HK. Neurobiology of lithium: an update. Journal of Clinical Psychiatry 1998;59(suppl 6):37-47.

25. Imahori Y, Fujii R, Ueda S, Ohmori Y, Wakita K, Matsumoto K. Phosphoinositide turnover imaging linked to muscarinic cholinergic receptor in the central nervous system by positron emission tomography. Journal of Nuclear Medicine 1993;34(9):1543-51.

26. Imahori Y, Ido T. Radioligands for imaging second messenger systems by positron emission tomography. Med Chem Res 1994;5:97-112.

27. Kato T. In vivo investigations of signal-transduction systems in affective disorders by magnetic resonance spectroscopy. In: Ozawa H, Saito T, Takahata N, editors. Signal transduction in affective disorders. Tokyo: Springer-Verlag; 1998. p. 133-46.

28. Berrettini WH, Ferraro TN, Goldin LR, et al. A linkage study of bipolar illness. Arch Gen Psychiatry 1997;54(1):27-35.

29. Gershon ES, Badner JA, Goldin LR, Sanders AR, Cravchik A, DeteraWadleigh SD. Closing in on genes for manic-depressive illness and schizophrenia. Neuropsychopharmacology 1998;18(4):233-42.

30. Gershon ES, Badner JA, Detera-Wadleigh SD, Ferraro TN, Berrettini WH. Maternal inheritance and chromosome 18 allele sharing in unilineal bipolar illness pedigrees. Am J Med Genet 1996;67(2):202-7.

31. Steen VM, Lovlie R, Osher Y, Belmaker RH, Berle JO, Gulbrandsen AK. The polimorphic inositol polyphosphate 1-phosphatase gene as a candidate for pharmacogenetic prediction of lithium-responsive manicdepressive illness. Pharmacogenetics 1998;8:259-68.

32. Berrettini W. Diagnostic and genetic issues of depression and bipolar illness. Pharmacotherapy 1995;15(6 Pt 2):69S-75S.

33. Ewald H, Eiberg H, Mors O. A search for genes predisposing to manic depressive illness on chromosome 20. Psychiatr Genet 1995;5(3):105-11.

34. Inayama Y, Yoneda H, Sakai T, et al. Lack of association between bipolar affective disorder and tyrosine hydroxylase DNA marker. American Journal of Medical Genetics 1993;48:87-9.

35. Ram A, Guedj F, Cravchik A, et al. No abnormality in the gene for the G protein stimulatory alpha subunit in patients with bipolar disorder. Archives of General Psychiatry 1997;54(1):44-8.

36. Vallada H, Craddock N, Vasques L, et al. Linkage studies in bipolar affective disorder with markers on chromosome 21. J Affect Disord 1996;41(3):217-21.

37. Tsiouris SJ, Breschel TS, Xu J, McInnis MG, McMahon FJ. Linkage disequilibrium analysis of G-olf alpha (GNAL) in bipolar affective disorder. Am J Med Genet 1996;67(5):491-4. 
38. Mendes de Oliveira JR, Otto PA, Vallada H, et al. Analysis of a novel functional polymorphism within the promoter region of the serotonin transporter gene (5-HTT) in Brazilian patients affected by bipolar disorder and schizophrenia. Am J Med Genet 1998;81(3):225-7.

39. Brown AS, Susser ES, Lin SP, Neugebauer R, Gorman JM. Increased risk of affective disorders in males after second trimester prenatal exposure to the Dutch hunger winter of 1944-45. British Journal of Psychiatry 1995;166:601-6.

40. Torrey EF, Miller J, Rawlings R, Yolken RH. Seasonality of births in schizophrenia and bipolar disorder: a review of the literature. Schizophr Res 1997;28(1):1-38

41. Brown GW, Moran P. Clinical and psychosocial origins of chronic depressive episodes. I: A community survey. British Journal of Psychiatry 1994;165:447-56.

42. Brown GW, Harris TO. Aetiology of anxiety and depressive disorders in an inner-city population. 1. Early adversity. Psychological Medicine 1993;23:143-54.

43. Brown GW, Harris TO, Eales MJ. Aetiology of anxiety and depressive disorders in an inner-city population. 2. Comorbidity and adversity. Psychological Medicine 1993;23:155-65.

44. Frank E, Anderson B, Reynolds CF, Ritenour A, Kupfer DJ. Life events and the research diagnostic criteria endogenous subtype. A confirmation of the distinction using the Bedford College methods. Archives of General Psychiatry 1994;51:519-24.

45. Post RM. Transduction of psychosocial stress into the neurobiology of recurrent affective disorder. American Journal of Psychiatry 1992;149:9991010 .

46. Post RM, Weiss SR, Smith M, Rosen J, Frye M. Stress, conditioning, and the temporal aspects of affective disorders. Annals of the New York Academy of Sciences 1995;771:677-96.

47. Soares JC, Gershon S. Prospects for the development of new treatments with a rapid onset of action in affective disorders. Drugs 1996;52:477-82. 48. Lydiard RB, Pottash AL, Gold MS. Speed of onset of action of the newer antidepressants. Psychopharmacology Bulletin 1984;20:258-71.

49. Overall JE. Justifying a "fast acting" claim for antidepressant drugs. Psychopharmacol Bull 1995;31:45-55.

50. Soares JC, Gershon S. The lithium ion: a foundation for psychopharmacological specificity. Neuropsychopharmacology 1998;19:167-82.

51 Kupfer DJ, Frank E, Perel JM, et al. Five-year outcome for maintenance therapies in recurrent depression. Arch Gen Psychiatry 1992;49(10):769-73.

52. Zornberg GL, Pope Jr. HG. Treatment of depression in bipolar disorder: new directions for research. Journal of Clinical Psychopharmacology 1993; 13:397-408.

53. Hlastala SA, Frank E, Mallinger AG, Thase ME, Ritenour AM, Kupfer DJ. Bipolar depression: an underestimated treatment challenge. Depress Anxiety 1997;5(2):73-83.

54. Hurowitz GI, Liebowitz MR. Antidepressant-induced rapid cycling: six case reports. Journal of Clinical Psychopharmacology 1993;13:52-6.

55. Persad E, Oluboka OJ, Sharma V, Mazmanian D, Kueneman K. The phenomenon of rapid cycling in bipolar mood disorders - a review. Canadian Journal of Psychiatry - Revue Canadienne de Psychiatrie 1996;41(1):23-7.

56. Winokur G, Black DW, Nasrallah A. Depressions secondary to other psychiatric disorders and medical illnesses. American Journal of Psychiatry 1988;145:233-7.

57. Brady KT, Sonne SC. The relationship between substance abuse and bipolar disorder. J Clin Psychiatry 1995;56 Suppl 3:19-24.

58. Frank E, Kupfer DJ, Ehlers CL, et al. Interpersonal and social rhythm therapy for bipolar disorder: Integrating interpersonal and behavioral approaches. Behavioral Therapist 1994;17:143-9.

59. Miller NL, Markowitz JC. Interpersonal psycotherapy of depressed patients. J. Pract. Psychiatry Behav Health 1999;5:63-74.

60. Mann JJ, Arango V. Integration of neurobiology and psychopathology in a unified model of suicidal behavior. Journal of Clinical Psychopharmacology 1992;12:2S-7S.

\section{Correspondência: Jair C. Soares}

Professor Assistente de Psiquiatria do Western Psychiatric Institute and Clinic - Centro Médico da Universidade de Pittsburgh. 3811 O'Hara Street, Pittsburgh, PA, 15213, USA. Phone: +1(412)383-3102. Fax: +1(412)383-3103. email: soares+@ pitt.edu 